\title{
A proposed model for the culture`s mode of influence on the entrepreneurial process
}

Francisco Liñán and Inmaculada Jaén

\section{Introduction}

Entrepreneurial intentions are considered a very relevant predictor of start-up behaviour (Kautonen, van Gelderen, \& Fink, 2015). This has so far served as a justification to focus solely on the study of entrepreneurial intentions. In contrast, the research specifically focusing on the transformation from intention to action is still scarce. Few longitudinal analyses have been performed to test the predictive capacity of intention. A recent literature review (Liñán \& Fayolle, 2015) found only 24 longitudinal studies out of 409 articles on entrepreneurial intentions, and only 20 of them focused on new venture creation (the remaining addressing firm growth). These limited results, nevertheless, overwhelmingly confirm that intention is a significant predictor of entrepreneurial action.

At the same time, the extant research also finds that the rate of transformation from intention to action is considerably low. Van Gelderen et al. (2015) find that nearly $70 \%$ of intentional entrepreneurs have not taken real action to start their ventures after one year. Thus, in order to actually understand how to transform entrepreneurial intention into action, there is a need to develop more complex models, taking into account other relevant variables. Many such variables have been proposed in the literature. Some authors have considered demographic/background elements, such as age, gender, experience and education (Langowitz \& Minniti, 2007; Levesque \& Minniti, 2006). Others have analysed the role of psychological variables (Van Gelderen et al., 2015). The analysis of economic conditions is relatively frequent (Carree, Van Stel, Thurik, \& Wennekers, 2007), and the role of culture and social conditions is also attracting considerable attention (Kibler, Kautonen, \& Fink, 2014; Liñán \& Fernandez-Serrano, 2014).

Regarding this latter element, culture is proposed in this chapter as an encompassing contextual element playing a very relevant role in explaining the process from intention to action. While a number of contributions have studied the role of culture in the configuration of entrepreneurial intentions (Liñán, Moriano, \& Jaén, 2016), others have analysed culture's effect on start-up rates (Pinillos \& Reyes, 2011). Elements such as the social legitimacy of entrepreneurship have been found to affect actual venture creation (Kibler et al., 2014).

Still, the question remains as to how culture affects the transformation of entrepreneurial intention into action. In this chapter, we focus on understanding how and to what extent national culture influences entrepreneurship, including entrepreneurial beliefs, motives, intentions and behaviours (Hayton \& Cacciotti, 2013). We argue that 
culture is made up of at least two elements: social cognition and societal legitimation. Each of these elements would have a different effect on either the entrepreneurial intention or its transformation into action. The relative influence exerted by each of these two components will determine the aggregate effect of culture on the entrepreneurial process.

This proposed model of cultural influence on entrepreneurship can also help explain some of the apparent paradoxes that have been found in the literature. In particular, there is considerable evidence that individualist values favour entrepreneurship (Liñán et al., 2016; Moriano, Palací, \& Morales, 2007; Yang, Hsiung, \& Chiu, 2015). At the same time, however, countries with a less individualistic culture exhibit higher levels of entrepreneurial intentions and start-up rates (Xavier, Kelley, Kew, Herrington, \& Vorderwülbecke, 2013). Despite several attempts to explain this contradiction (Pinillos \& Reyes, 2011), the issue is still far from settled.

\section{Measuring culture}

Culture may be defined as the set of basic common values which contributes to shaping people's behaviour in a society (Inglehart, 1997). It also includes patterns of thinking, feeling and acting, which are learned and shared by people living within the same social environment (Hofstede \& Hofstede, 2005). Hence, at least two components of culture are identified: values and behaviours. Regarding its effect on entrepreneurship, few consolidated "truths" may still be claimed. In fact, the interdisciplinarity inherent to this field of research can lead to substantial challenges in theory development, since scholars may emphasise different theoretical lenses, languages, research questions and methods (Hayton \& Cacciotti, 2013).

The first and most common classification of cultures distinguishes between individualist and collectivist ones (Hofstede, 1980; Schwartz, 1999; Triandis, 1995). Yet, alternative characterisations have also been made. From an empirical point of view, Hofstede's cultural dimensions of individualism, uncertainty avoidance, power distance and masculinity (Hofstede, 1980, 2003; Hofstede \& Hofstede, 2005) have been frequently used as a reference in research about the influence of culture on entrepreneurship (Hayton, George, \& Zahra, 2002; Liñán \& Chen, 2009; Mueller, Thomas, \& Jaeger, 2002). Results have confirmed their influence on national start-up rates, innovation or entrepreneurial intentions. Notwithstanding, conflicting results have recently emerged (Hayton \& Cacciotti, 2013). Hofstede's measures have been criticised as having methodological weaknesses, being very old and lacking a theory-driven development base (Cullen, Johnson, \& Parboteeah, 2014; Jabri, 2005; Tang \& Koveos, 2008).

More recently, scholars have also applied Schwartz's (1990) cultural value structure to the study of entrepreneurship (De Clercq, Lim, \& Oh, 2014; Hirschi \& Fischer, 2013; Holland \& Shepherd, 2013; Liñán \& Fernandez-Serrano, 2014; Liñán, Fernández- 
Serrano, \& Romero, 2013; Yang et al., 2015). Its seven cultural value orientations are classified into three bipolar dimensions addressing three basic social problems: (a) individuality vs. group membership (opposing autonomy and embeddedness orientations), (b) getting societal tasks done (opposing egalitarianism and hierarchy) and (c) mode of interaction with others and with nature (opposing harmony and mastery) (Schwartz, 2006, 2008). Recent work has shown that they interact with wealth in influencing different types of entrepreneurial activity (Liñán et al., 2013). At the same time, they are also useful in explaining international investment decisions (Siegel, Licht, \& Schwartz, 2013), and seem to moderate the impact of regulatory barriers on entrepreneurship (Fernández-Serrano \& Romero, 2014).

Steenkamp (2001) proposes an empirical integration of both theories, for which there seems to be some theoretical bases (Schwartz, 2009). So, for the purposes of this chapter, we will follow most of Steenkamp's (2001) recommendations by considering four aspects or dimensions of culture. Accordingly, we will firstly consider "individualismcollectivism" as related to the corresponding Hofstede's dimension, and to Schwartz's autonomy-embeddedness dimension. Secondly, we will refer to "power and social stratification" as encompassing power distance ${ }^{1}$ (Hofstede) and egalitarianism-hierarchy (Schwartz). Thirdly, Hofstede's masculinity and Schwartz's harmony-mastery dimensions will be considered under the label of "competitiveness and attitude to others". Finally, "attitude to risk and uncertainty" will also be considered as a cultural dimension potentially affecting entrepreneurship. We are conscious that this integration is not without problems, but it will serve to illustrate the different mechanisms through which culture may operate affecting the entrepreneurial process, without the debate between alternative cultural theories diverting attention from our main aim.

\section{Understanding the influence of culture}

In a recent review, Hayton and Caciotti (2013) identify two main research streams regarding the impact of national culture. Firstly, it may influence aggregate entrepreneurial activity by either promoting innovation (Williams \& McGuire, 2010), or by facilitating the actual starting of new ventures (Pinillos \& Reyes, 2011). Secondly, it may affect the individual characteristics of entrepreneurs; either modifying their values and motives (Pruett et al., 2009), or the mechanism conforming each person's entrepreneurial intention and the level of this variable (Jaén \& Liñán, 2015). In this sense, culture may be seen as "both values and actual ways in which members of a culture go about dealing with their collective challenges" (Javidan, House, Dorfman, Hanges, \& De Luquet, 2006, p. 899). Consequently, as mentioned above, culture should be considered

\footnotetext{
${ }^{1}$ Steenkamp (2001) found power distance to correlate with the individualism/collectivism dimension. Nevertheless, Hofstede also had difficulties in empirically differentiating both dimensions and still proposed power distance as an independent dimension (Earley \& Gibson, 1998). Our decision is based on conceptual proximity between power distance and the egalitarianism-hierarchy dimension.
} 
as comprised of two main elements: values and practices (Autio, Pathak, \& Wennberg, 2013; Krueger, Liñán, \& Nabi, 2013; Stephan, Uhlaner, \& Stride, 2015).

The first such element relies on the definition of culture as shared values. According to this, the majority of individuals in that society will share some personal values that are similar to the predominant cultural values (Schwartz, 2008). Therefore, if some cultural values are identified as leading to an entrepreneurially supportive culture, we can expect a larger fraction of that culture's members to stress those values and, for this reason, be themselves classified as more pro-entrepreneurial individuals.

This influence corresponds to what Davidsson (1995) calls the "psychological traits approach", and has more recently been termed as social cognition (Fiske \& Taylor, 2013). It refers to the transmission of values, beliefs and motivations among the different members of society (Autio et al., 2013). Family and peer group shape the socialisation process of persons and transmit their values and beliefs to new members (Boehnke, 2001; Phalet \& Schonpflug, 2001). Of course, there is a wide intra-social variation in personal preferences (Fischer, 2006; Fischer \& Schwartz, 2011), but there is a cultural element in the intergenerational transmission of values and beliefs. From this perspective, a more pro-entrepreneurial culture should reflect itself in more prevalent pro-entrepreneurial motivations of society members (Jaén \& Liñán, 2013). Thus, more individuals will exhibit the kind of values and attitudes that are associated with entrepreneurial activity (McGrath, MacMillan, Yang, \& Tsai, 1992; Mueller \& Thomas, 2001; Stephan et al., 2015). As a result, they will be more likely to develop individual cognitive processes leading to the formation of strong entrepreneurial intentions (Bird, 1988; Busenitz \& Lau, 1996).

The second transmission mechanism from culture to entrepreneurship is societal legitimation. This implies the predominance of certain cultural values and norms leading to the social acceptance and support of entrepreneurship (Autio et al., 2013). Even if individuals do exhibit a high entrepreneurial intention, acting on this personal intention implies several forms of social interaction, and the decision will be affected by the expected reactions of others (Leung \& Morris, 2015). A supportive culture makes an entrepreneurial career more valued and socially recognised, hence creating a favourable institutional environment (Thornton, Ribeiro-Soriano, \& Urbano, 2011; Urbano \& Alvarez, 2014). This mechanism works through social institutions and their actions (via legislation, government directives or the education system), selecting and prioritising some behaviours over the others. Accordingly, the formal (and informal) institutional framework will be conformed in such a way so as to facilitate the implementation of entrepreneurial behaviours on the part of any citizen (Liñán et al., 2013). In this regard, institutions are shaped to make entrepreneurship a socially appropriate behaviour (Bourdieu, 1991; Markus \& Kitayama, 1991; Schwartz, 1994).

Societal legitimation establishes what is socially accepted and what is not (Javidan et al., 2006). It works through societal compliance mechanisms, represented by formal and informal institutions (Autio et al., 2013). That is, we are referring to objective norms and rules: either formal, such as the start-up procedures, or the legal regulation of business 
activity; or informal such as the existence of trust, the functioning of social networks, or the so-called "trade practices" (Thornton et al., 2011; Urbano \& Alvarez, 2014). As Leung \& Morris (2015, p. 1034) explain, "cultural differences in judgement patterns are carried more by perceived descriptive norms than by personal beliefs or values." That is, perceived cultural practices are more important in determining what the individual feels as accepted by society.

Recent research has confirmed that the social legitimacy of entrepreneurship is a relevant variable in predicting entrepreneurial behaviour (Kibler \& Kautonen, 2014; Kibler et al., 2014). If the creation of new firms becomes easier (socially legitimate), more ventures will be launched (Etzioni, 1987). Positive societal legitimation of entrepreneurship facilitates access to social capital and other external resources (Liao \& Welsch, 2005), and it results in speedier and simpler procedures to start a venture (Fernández-Serrano \& Romero, 2014). Thus, this will contribute to individuals perceiving their environment to be more favourable (munificent) for entrepreneurial activity (Kibler et al., 2014). In turn, opposing cultural practices will make the individual face greater difficulties and "social sanctions" in starting up, consequently reducing actual start-up rates (Stephan et al., 2015).

On the other hand, cultural values (social cognition) would be a stronger element shaping personal behaviour in situations where there are no established social rules of conduct. In this case, personal preference (values and beliefs) would become the relevant variable. "An implication of this argument is that values would shape behaviour more in situations lacking strong signals of social adaptation" (Leung \& Morris, 2015, p. 1038). That is, where there is no social interdependence and no perceived pressure to behave in any given direction, personal values are the important element ${ }^{2}$.

In this study, we argue that both social cognition and societal legitimation mechanisms play a crucial role in the entrepreneurial process, as shown in Figure 1. Social cognition will be reflected in the personal values, attitudes and intentions of individuals, making them more or less inclined towards entrepreneurship (Autio et al., 2013; Leung \& Morris, 2015). In contrast, societal legitimation will have a direct effect on the evaluation of the social rewards and sanctions involved in actually acting on this intention (Stephan et al., 2015). Thus, the influence of culture on entrepreneurship would be the result of both social cognition and societal legitimation mechanisms functioning together. In the next section, we argue that this influence of culture will also depend on the specific economic conditions of each country. Accordingly, we expect to find relevant interaction effects between the income level and culture in explaining entrepreneurship.

\footnotetext{
${ }^{2}$ Autio et al. (2013) identify a middle mechanism labelled as "collective action". This refers to collective expectations and shared norms. It includes an element of social cognition (helping establish the personal values and beliefs about optimal social situations and interactions), and an element of societal legitimation (establishing tacit norms about expected behaviours in society). In what follows, for reasons of clarity, we will only consider the two main mechanisms described above (social cognition and societal legitimation).
} 
Figure 1. Culture's influence on the entrepreneurial process

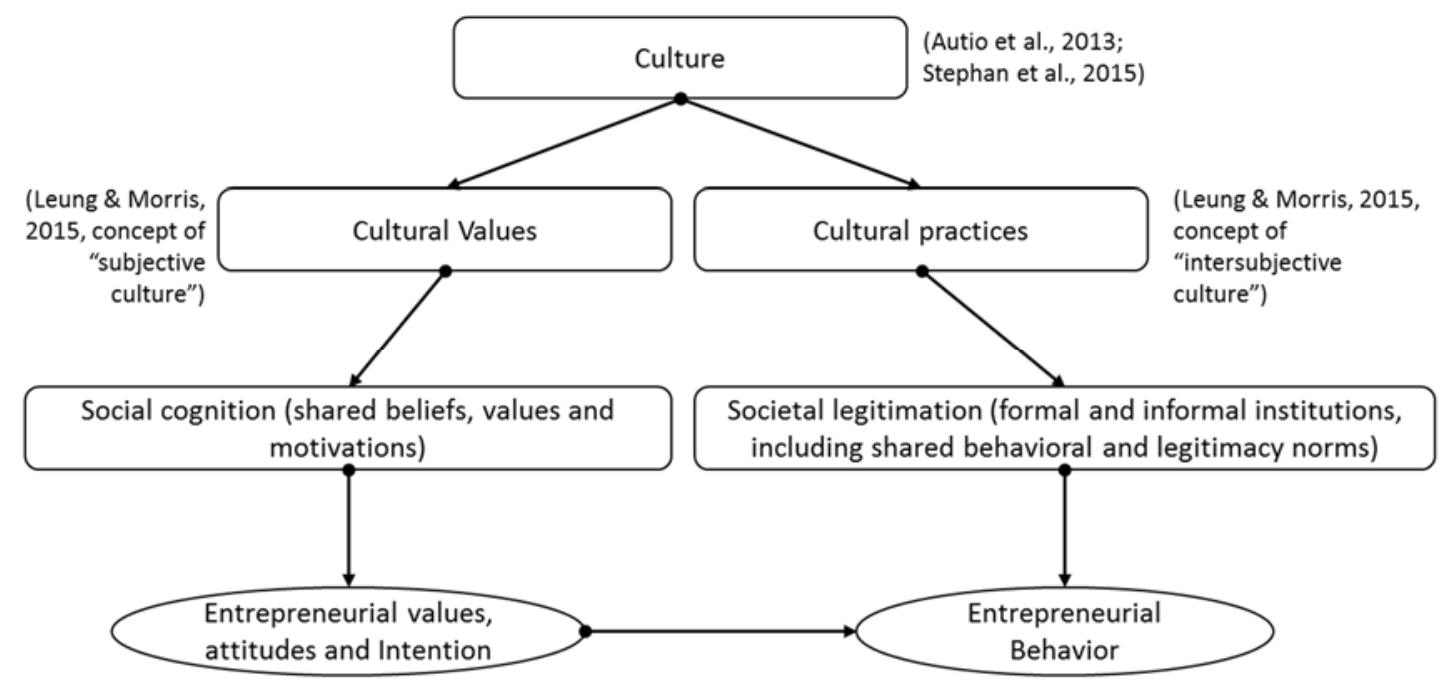

Source: Self-elaboration based on Autio et al. (2013), Leung \& Morris (2015) and Stephan et al. (2015).

\section{Economic development and entrepreneurship}

Entrepreneurship plays a very important role in the process of economic development. It increases employment opportunities, enhances the level of technical innovations, and promotes economic growth (Audretsch \& Fritsch, 1999; Fritsch \& Mueller, 2004; Reynolds, Bygrave, Autio, \& Hay, 2002; van Stel \& Storey, 2004). From a dynamic perspective, entrepreneurs are agents of change since entrepreneurship implies starting new businesses, experimenting with new techniques and a new organisation of production, introducing new products or even creating new markets (Wennekers, Uhlaner, \& Thurik, 2002).

However, development is generally accompanied by an increased demand for labour -especially qualified labour- and, therefore, higher real wages. Hence, the opportunity costs of self-employment would rise. Consequently, higher Gross Domestic Product per capita (GDPpc) could reduce the entrepreneurial activity (Bjornskov \& Foss, 2006; Noorderhaven, Thurik, Wennekers, \& van Stel, 2004). In particular, the more complex characteristics of the economic system may require successful ventures to be started by highly qualified individuals (Cullen et al., 2014), who in turn, are those with better prospects in the labour market. This negative effect of income on entrepreneurship could thus be even more relevant for opportunity-based entrepreneurial activity.

At the same time, Minniti, Bygrave and Autio (2006) and Lee and Peterson (2000) argue that there may be a positive effect of the income level on entrepreneurial activity, at least for industrialised economies. In these economies, it is argued, a higher GDPpc 
favours entrepreneurship (Fishman \& Sarria-Allende, 2004; Parker \& Robson, 2004). Economic development induces new firm formation since the opportunities and expected rewards of starting a business are higher (Carree, van Stel, Thurik, \& Wennekers, 2002; Reynolds, Storey, \& Westhead, 1994). Furthermore, the level of income and wealth determines the variety of consumer demand. A high differentiation in demand benefits the suppliers of new and specialised products and diminishes the scale advantages of large incumbent firms (Jovanovic, 1993; Wennekers et al., 2002).

Nevertheless, the relative importance of these positive effects of higher income on entrepreneurship are expected to be relatively small when compared to the increase in the opportunity costs of entrepreneurship as labour markets and organisations are developed. In particular, for developing countries, the increased demand for labour should outweigh any positive effects of income growth on the supply of entrepreneurs (Naudé, 2010; Poschke, 2013). Consequently, we expect a generally negative relationship between the GDPpc and entrepreneurship. Nonetheless, it could be less so for higher levels of income (Carree et al., 2002; Liñán et al., 2013; Sternberg \& Wennekers, 2005; Wennekers, van Stel, Thurik, \& Reynolds, 2005). In this sense, some authors (van Stel, Wennekers, Thurik, Reynolds, \& de Wit, 2003; Verheul, Wennekers, Audretsch, \& Thurik, 2002) suggest a U-shaped influence of income on entrepreneurship. Yet recent data fail to confirm this relationship (Kelley, Singer, \& Herrington, 2016). Additionally, we argue that culture and its possible interactions with the income level may be relevant in this respect, as will be discussed below. For this reason, the following proposition is formulated:

P1: The income level is negatively related to entrepreneurship, but the effect may be weaker for higher levels of income.

\section{The interaction of culture and economic conditions in entrepreneurship}

A considerable interdependence between culture and economic development is found in practice (Liñán \& Fernandez-Serrano, 2014; Mueller et al., 2002; Ros, 2002). Less developed countries are typically characterised by a predominance of collectivism and high power and social stratification, while individualism and low stratification tend to prevail in developed countries (Schwartz, 2008; Tang \& Koveos, 2008). In turn, when competiveness and attitude to others and attitude to uncertainty and risk are considered, no evidence of a clear relationship with economic development is found (Schwartz, 2008; Tang \& Koveos, 2008).

In low-income countries, where economic activity is relatively simpler and formal economic institutions are less developed, there is a greater need for economic actors to resort to social (non-economic) interactions to be able to carry out economic activity (Bianchi, 2010; Naudé, 2010). In this sense, societal norms and practices are probably more important in determining personal actions. According to Baker et al. (2005), the 
perceived societal legitimation (cultural practices) will shape the expected (and actual) results of the social interactions needed to start a firm. Cultural practices shape formal and informal institutions, making new venture creation easier (or more difficult). This, in turn, is more strongly related to actual economic activity and the income level. Since entrepreneurship is an inevitably social activity, societal legitimation will probably play a predominant role, in interaction with the income level, when determining entrepreneurship. For this reason, societal legitimation (cultural practices) will be more relevant in determining individual entrepreneurial behaviour, especially in developing countries.

As the economy advances towards higher stages of development, former practices and regulations become obsolete and inadequate (North, 1995; Williamson, 2000). Cultural practices are adapted to new forms of activity, leading to a transformation of formal and informal institutions. The specific forms that this institutional transformation take will differ depending on the predominant culture in that society (Tabellini, 2010). While it is often relatively easier to modify formal economic institutions by policy action, informal institutions are likely to resist change and take time to evolve towards new social norms (Stephan et al., 2015; Thornton et al., 2011). Informal institutions act as the background conditions against which the more proximate formal institutions operate (De Clercq et al., 2014). Therefore, different combinations of the cultural dimension and income level will result in different practices. This, in turn, will have an effect on entrepreneurship, depending on whether the practices have changed in a direction that is more or less favourable to entrepreneurship.

In contrast, the effect of social cognition (cultural values) could be expected to remain stable across different economic conditions. Both in developing and developed countries, pro-entrepreneurial values -when transmitted to individuals in the society- will result in the development of more favourable entrepreneurial beliefs, attitudes and intentions by these individuals (Iakovleva, Kolvereid, \& Stephan, 2011). That is, for any given combination of income and cultural practices, a more favourable social cognition will result in a larger share of society members exhibiting a high entrepreneurial intention and (all else being equal) higher start-up rates (Kautonen, Van Gelderen, \& Tornikoski, 2013; Kibler \& Kautonen, 2014; Krueger, Reilly, \& Carsrud, 2000).

In the case of high-income countries, institutions are highly developed and economic activity is carried out through market interactions (Bianchi, 2010; Naudé, 2010). Greater economic development will imply better functioning institutions, which will be better aligned with the needs of modern economic activity. In this context, there is relatively less social exposure when taking economic decisions, and a personal preference (partly determined by the predominant cultural values) becomes more prominent (Leung \& Morris, 2015). Accordingly, the contribution of social cognition (cultural values and beliefs) to determining individual entrepreneurial behaviour is relatively more important than societal legitimation, as compared to the case for developing countries. 
P2: The relative influence of social cognition (cultural values) and societal legitimation (cultural practices) on entrepreneurship changes with the economic development level. In developing countries, societal legitimation prevails. In developed countries, the relative importance of social cognition is higher.

\section{Individualism, income level and entrepreneurship}

There is considerable evidence regarding the relationship between the cultural dimension of individualism/collectivism and entrepreneurial activity (Liñán et al., 2013; Shane, 1993; Tiessen, 1997). In collectivistic countries, cultural values will stress prioritising group interest over personal aims (Earley \& Gibson, 1998). This could be initially conducive to lower entrepreneurial intention, through the social cognition effect. In this respect, personal-level individualism is found to promote entrepreneurial intention and action (Hirschi \& Fischer, 2013; Holland \& Shepherd, 2013; Liñán et al., 2016; Yang et al., 2015), while the opposite is true for personal-level collectivistic values. At the same time, however, cultural practices stress the importance of group membership, solidarity and cooperation. This implies that economic activities will be carried out to pursue group interests and any group member will feel an obligation to contribute to its success (Earley \& Gibson, 1998).

The level of economic development will, in this respect, play a significant role. In developing countries, where formal markets and institutions are often lacking, strong embeddedness could strengthen and promote entrepreneurial behaviour. The sense of community would provide support for in-group nascent entrepreneurs, facilitating the access to basic resources within the group (Cullen et al., 2014; De Clercq et al., 2014). In a context where markets for most resources do not exist, are inefficient, or subject to corruption, the resources controlled by in-group members (not only funding, but also labour, land, or even machinery which is not easily accessible through the market) are essential for the venture to be able to survive (Bianchi, 2010; Naudé, 2010). Without them, the viability of the new venture is impossible. Thus, entrepreneurship becomes necessarily a collective endeavour. Group members consider entrepreneurial activity as the socially legitimate practice in this environment.

In this context, The inexistence of a well-developed labour market in which offering themselves as employees will make them take entrepreneurship as the socially expected route, irrespective of their personal values and inclinations. The opportunity cost of entering into entrepreneurship is very low or inexistent, due to the undeveloped (or insufficiently developed) labour market (Poschke, 2013).

Additionally, the sense of obligation to the group makes its members more willing to start up if this is what other group members expect from them, and guarantees support from the remaining members of the family or group (Earley \& Gibson, 1998). Hence, to the extent that entrepreneurial activity involves participation by group members in 
providing resources, funding and support, collectivism facilitates entrepreneurship. Nascent entrepreneurs have access to resources (funding, labour, etc.) through in-group relationships (Cullen et al., 2014; De Clercq et al., 2014). In particular, this kind of ventures created out of a sense of obligation to the family or inner group are facilitated by the economic characteristics of these countries (Bianchi, 2010; Naudé, 2010).

In contrast, a culture stressing individualism in developing countries does not help entrepreneurship. It may lead to individuals with positive entrepreneurial attitudes and intention (through cultural values). All the same, the economic conditions make entrepreneurship more difficult due to the lack of institutions and markets (Bianchi, 2010; Naudé, 2010). In this sense, societal practices will discourage entrepreneurship, since attempting a new venture faces high obstacles. The predominance of individualistic values would lead to less support and solidarity within the family or in-group (Earley \& Gibson, 1998). The nascent entrepreneur will receive less help from other group members (in the form of providing resources needed by the venture), who will not feel any obligation to contribute to the project. In this context, given the difficulties in accessing the necessary resources through alternative routes (market, public provision, etc.) (Bianchi, 2010), the entrepreneur will feel the individualistic cultural practices to be negative and detrimental and will be less likely to decide to act (Noseleit, 2010; Wdowiak, Schwarz, Breitenecker, \& Wright, 2007).

As the economy advances, the institutional environment improves and formal and informal institutions work better, facilitating a normalised access to resources through well-developed markets (De Clercq et al., 2014). In this alternative environment, collectivism imposes cultural practices that are detrimental to entrepreneurial action. The need to abide by collective decisions is seen here more as an impediment than a facilitating factor. In this situation, people perceiving that the society attaches too much importance to groups may feel constrained to pursue their inner goals. Pressure to conform to group interests, to hire in-group workers or suppliers, to trade within the group or to use only group-resources will limit the options to develop their projects' potential fully (Cullen et al., 2014; De Clercq et al., 2014). In a highly-developed but collectivistic society, the expected difficulty in the access to quality and less costly resources, due to perceived pressure to conform to group-member suppliers, workers, etc., will reduce the expected profitability and chances of survival (Bianchi, 2010; Naudé, 2010). In addition, resource acquisition by entrepreneurs is likely to be more difficult in collectivist societies (Henrekson, 2005), as key stakeholders may withhold important resources necessary for the start-up process. This, in turn, reduces the likelihood of entrepreneurial intentions being transformed into entrepreneurial behaviour (Cullen et al., 2014; De Clercq et al., 2014).

Entrepreneurs will see a conflict between either pursuing their projects at the expense of opposing what they feel are the prevailing social norms (thus risking social sanctions), or pursuing a project that is weakened by group pressure limitations, or simply abandon the project. Overall, then, acting on their intentions may increase the perceived potential 
loss and as a result cause anxiety to these individuals in relation to implementing gestation activities (Van Gelderen et al., 2015). Consequently, higher perceived in-group collectivism is likely to affect start-up behaviours negatively. The entrepreneur perceives that this kind of entrepreneurial behaviour will not be appreciated and accepted by society, which leads to higher legitimacy costs of entrepreneurship (Kibler et al., 2014).

In the case of social cognition, its role will be more relevant in developed countries. In them, an individualistic culture is associated with the values of stimulation and selfdirection (Schwartz, 1999). Individuals sharing these values appreciate independent thought and action and enjoy the excitement and challenge of life (Schwartz, 1992). They explore new ways of doing things (Holland \& Shepherd, 2013), using their intellectual capacity to develop new products and services (Shane, Kolvereid, \& Westhead, 1991). Berings and Adriaenssens (2012) find that the values of innovation and creativity have a positive influence on the enterprising interest of students. So, when individualism prevails, more people will exhibit entrepreneurial values, attitudes and intention, leading to higher start-up rates (all else being equal) (Yang et al., 2015). In contrast, collectivistic cultural values are related to stability, preservation of traditions, and moderation in action (Schwartz, 1992). Individuals sharing these values will be inclined to preserve the status quo, sticking with traditional roles (Lyons, Duxbury, \& Higgins, 2007). A strongly collectivistic culture is less likely to be identified with individuals stressing favourable attitudes towards entrepreneurship, leading to a lower entrepreneurial intention and for this reason negatively affecting start-up behaviour.

P3a: Individualism (as opposed to collectivism) increases entrepreneurial motivation and intention irrespective of the level of economic development, through the social cognition mechanism (cultural values).

P3b: Individualism (as opposed to collectivism) affects entrepreneurial action differently depending on the level of economic development through the societal legitimation mechanism (cultural practices). In developing countries a collectivistic culture favours entrepreneurial action, while in developed countries individualism favours entrepreneurial action.

\section{Power and social stratification, income level and entrepreneurship.}

In hierarchy-prevalent societies, powerful incumbents feel entitled to protect their position and privileges, limiting access to the resources and information for entrepreneurial activity, and to the knowledge structures needed to exploit them (De Clercq et al., 2014). Thus, individuals considering the starting of a new venture will perceive cultural practices as making it difficult to secure the resources needed. Highly stratified societies tend to stress the need to accept the position one has in society (Schwartz, 2006). The position and privileges of powerful incumbents are taken for granted and not challenged. In this context, entrepreneurship represents a threat to this 
position. It will accordingly be seen as socially deviant behaviour with high legitimacy costs (Autio et al., 2013). Meanwhile, in low power and stratification societies, societal practices will tolerate entrepreneurship as an acceptable path to vertical mobility. For these reasons, societies that are more egalitarian should tolerate entrepreneurship by means of societal legitimation (cultural practices).

Regarding social cognition, the values transmitted to society members by high power distant cultures would stress power and wealth (Schwartz, 2006), rather than the opposite values of universalism and commitment. They will stress the preservation of the status quo and the assumption of traditional roles. In contrast, in less stratified or less power distant societies, individuals' attempts to improve their social and economic status would be seen as legitimate goals (Schwartz, 2006). Social status is not "given" from birth (as is the case in hierarchy-dominated cultures), but rather it is considered to be the result of personal effort and contribution to society. Hence, cultural values stress contribution and responsibility, which would lead to higher entrepreneurial motivations and intentions through social cognition mechanisms. It may be argued that universalism and commitment would be related to social entrepreneurship, as a way to contribute to society's wellbeing (Hoogendoorn, 2016). In this sense, Yang et al. (2015) found universalism to positively relate to entrepreneurial intentions, while power values were negatively related. Overall, then, we could expect egalitarianism cultures to transmit values contributing to individuals exhibiting higher entrepreneurial intentions.

Therefore, since both societal legitimation and social cognition mechanisms concur, a generally positive relationship between low power and social stratification (egalitarianism or low power distance) and entrepreneurship should be expected. However, we argue that this relation will be stronger in developed countries. The predominance of fewer social stratification cultural practices (egalitarianism) will lead to a functioning of formal and informal institutions in a way that facilitates responsible action, and a contribution to society and honesty (Schwartz, 1999). This environment is especially beneficial in a complex economic system, where the role of education and human capital is more important in explaining economic activity (Gennaioli, La Porta, Lopez-de-Silanes, \& Shleifer, 2013). In this context, a fairer access to education and equal rights allows the best-prepared individuals to be able to take advantage of spotted entrepreneurial opportunities (Shane \& Venkataraman, 2000).

In contrast, a predominance of hierarchy practices is more detrimental to entrepreneurship in highly developed countries, since an unequal distribution of roles and power will prevent those more qualified from launching their ventures (De Clercq et al., 2014). In turn, less skilled individuals from the smaller elite groups will be granted a "natural" right to start up. This is probably inefficient in any situation, but it may be more so in developed countries, where more complex opportunities are available and the skills needed are more specialised (Shane \& Venkataraman, 2000). In developing countries, in turn, simpler ventures are created and there would be less difference in the endowment of 
the basic skills needed. In high-income countries, then, privileged access to entrepreneurship by less skilled individuals is more of a problem.

P4a: Low power and social stratification (as opposed to hierarchy and power distance) increase entrepreneurial motivation and intention irrespective of the level of economic development, through the social cognition mechanism (cultural values).

P4b: Low power and social stratification (as opposed to hierarchy and power distance) facilitate entrepreneurial action through the societal legitimation mechanism (cultural practices). This effect is stronger for highly-developed countries due to the economic system and entrepreneurial opportunities being more complex and demanding higher skills and specialised resources.

\section{Competitiveness and attitude to others, income level and entrepreneurship.}

In this dimension, a predominance of competitive (masculinity or mastery) social values will lead to institutions (both formal and informal) legitimising the active pursuit of individual betterment, even at the expense of others (Schwartz, 2006). "Exploitation of resources and people for the sake of progress and change takes precedence" (Schwartz, 2009 , p. 142). Individuals are seen as having to compete and it is legitimate to use others, and nature, as a means to reach one's own aims. Starting a venture will be seen as a viable practice to try to improve the individuals' personal situation (Liñán \& Fernandez-Serrano, 2014). This is compatible with a weaker network of social protection (Schwartz, 2009), and difficulties in the labour market will thus result in a higher start-up rate (necessity entrepreneurship). One would as a result expect cultural practices and institutions that facilitate the creation of new ventures. This should promote entrepreneurship in both developing and developed countries.

Regarding the role of social cognition, the predominance of mastery values should be associated with a higher need for achievement at the individual level (Schwartz, 2006). This personal value has been related to entrepreneurship (Yang et al., 2015). People stressing achievement values are often prepared to invest time and effort to demonstrate competence and success in their endeavours (Bardi \& Schwartz, 2003). They believe that building a successful venture can result in a positive public image and influential positions in social circles (McGrath et al., 1992).

For this reason, both through social cognition and societal legitimation, a positive relationship between a competitiveness-dominated culture and entrepreneurship should be expected. Since entrepreneurship represents the attempt to change economic and competition conditions in the market, it would be favourably valued in societies stressing masculinity or mastery values. In contrast, harmony-prevalent cultures would be associated with a lower entrepreneurial activity. No significant interaction effect with the income level is expected in explaining entrepreneurial activity. 
P5a: A high competitiveness attitude towards others (as opposed to harmony and low masculinity values) increase entrepreneurial motivation and intention through the social cognition mechanism (cultural values).

P5b: A high competitiveness attitude to others (as opposed to harmony and low masculinity values) facilitates entrepreneurial action through the societal legitimation mechanism (cultural practices), irrespective of the level of economic development.

Attitude to uncertainty and risk, income level and entrepreneurship.

This cultural dimension refers to the extent to which the members of a culture feel threatened by uncertain or unknown situations (Hofstede \& Hofstede, 2005). In cultures with a highly negative attitude to uncertainty and risk, people are more easily threatened by ambiguous situations. These societies tend to develop institutional mechanisms to reduce the perceived ambiguity. In them, there is a tendency to rely on more extensive forms of planning (Shane, 1993) and explicit plans and predictions are of greater normative importance (Hofstede \& Hofstede, 2005).

From a social cognition perspective, one should expect that a negative attitude to uncertainty would lead people to exhibit lower entrepreneurial intentions. In particular, the attitude to entrepreneurship would be negative as implying some risk of failure and uncertain prospects of success (Douglas \& Shepherd, 2000, 2002). In this sense, the attitude to risk has been found to be negatively related to the entrepreneurial intention and its motivational antecedents (Douglas \& Shepherd, 2002; van Gelderen et al., 2008).

Similarly, in the case of societal legitimation, uncertainty acceptant societies will have less detailed social norms regulating social interactions. Consequently, there will be more opportunities in which no strong social rules exist and the importance of cultural values would be more prevalent in determining action (Leung \& Morris, 2015). In turn, a negative attitude to uncertainty will lead to more regulated social interactions, with a prescribed course of action for almost every situation. So, societal legitimation will be the most important element in determining action, and the influence of personal values will be the lowest (Leung \& Morris, 2015).

P6a: A tolerant attitude to uncertainty and risk increases entrepreneurial motivation and intention irrespective of the level of economic development, through the social cognition mechanism (cultural values).

P6b: A tolerant attitude to uncertainty and risk diminishes the presence and importance of the societal legitimation mechanism (cultural practices) in entrepreneurship. 


\section{Discussion}

Probably the first question to be addressed is related to the cultural theory adopted. In this chapter, we have embraced a hybrid model based on Steenkamp (2001), which integrates Hofstede's (1980) and Schwartz's (1999) approaches. Yet our purpose is not to claim its superiority over each of the original theories. On the contrary, we have aimed to skip the debate about competing cultural theories, and focus exclusively on its influence on the entrepreneurial process. We leave it for future research to adapt this model to each one of these original theories, or to a third one.

A second element to be addressed relates to the specific effect of social cognition on the different motivational antecedents of intention. It may be relatively straightforward to argue that individualist values will contribute to developing a favourable personal attitude towards entrepreneurship (Yang et al., 2015). The effect on perceived behavioural control, or self-efficacy, may not be so obvious. Still, it may be argued that achievement-related values (such as those stressed by the competitive -masculine or mastery- cultural dimension) could be positively related to perceived behavioural control (McClelland, 1961; Rauch \& Frese, 2007).

In contrast, the effect of cultural values on subjective norms via social cognition is expected to be substantially more complex. In this chapter, we have assumed that the effect of the social cognition mechanism on entrepreneurial intention is unidirectional and consistent across cultures (pro-entrepreneurial values increase intention). However, it may be argued that collectivism and high social stratification contribute to increasing the perceived subjective norm, since it represents the expected approval of the entrepreneurial decision by important referent people (Ajzen, 1991; Krueger et al., 2000). Hence, collectivistic and socially stratified societies would be contributing to increasing the entrepreneurial intention of its citizens through the effect of cultural values on subjective norms. This will be specially relevant to the extent that subjective norms are more important predictors of the entrepreneurial intention in collectivistic societies (Liñán \& Chen, 2009). Nonetheless, this latter result has not been confirmed in a more recent multicountry study (Moriano, Gorgievski, Laguna, Stephan, \& Zarafshani, 2012). Much research is still needed to gain a deeper understanding of the role of subjective norms in the culture-intention relationship.

The implications that may be derived from this approach are numerous. Firstly, the relationship from economic development to entrepreneurship can no longer be considered on its own. Attention has to be paid to culture, especially in multi-country studies or international comparisons. The conflicting results found in the literature (Kelley et al., 2016; Pinillos \& Reyes, 2011; van Stel et al., 2003; Verheul et al., 2002) might be explained through the inclusion of culture. If this latter variable is not adequately reflected, the analysis would suffer from a potentially substantial omitted-variable bias.

Secondly, the role of culture has to be investigated much further. We have enunciated some propositions about the modes of influence of each cultural dimension on the 
entrepreneurial process. Notwithstanding, these propositions are still general and need to be operationalised to empirically test their applicability. Nevertheless, the data on cultural values and practices is difficult to gather. The GLOBE project includes differentiated data on values and practices (House, Javidan, Hanges, \& Dorfman, 2002); but culture is not measured by strictly following either Hofstede's (1980) or Schwartz's (1999) theories. The compatibility of the GLOBE's measures with the cultural dimensions considered in this chapter needs to be investigated accordingly.

Additionally, a third mechanism of influence from culture to entrepreneurship has also been proposed, and is not considered in this chapter. This relates to the idea that entrepreneurs are "different" to other people. It has been argued that the level of valuecongruence between individuals and their culture is important in explaining entrepreneurial behaviour (Noorderhaven et al., 2004). In particular, "outlier individuals" -not sharing predominant cultural values- may be more prone to becoming entrepreneurs. In this sense, Rauch et al. (2013) find that both personal and cultural values affect the innovation-growth relationship in firms, with the strongest effect occurring when the difference between some of the personal and cultural values is highest. All the same, little is yet known about the "social deviance" between personal and cultural values, and the interaction process (Fayolle, Liñán, \& Moriano, 2014; Liñán et al., 2016). The extent to which this phenomenon is relevant in entrepreneurship research remains to be investigated.

Finally, even though most of the existing research has tended to identify culture with nation, some studies have challenged this traditional identification (García-Cabrera \& García-Soto, 2008). The existence of intra-national cultural differences should be acknowledged (Sackmann \& Phillips, 2004). Thus, regional variations in cultural values may contribute to explaining differences in entrepreneurship levels within a country (Davidsson, 1995; Davidsson \& Wiklund, 1997; Jaén \& Liñán, 2013). Therefore, subnational cultures (regions, ethnic groups) have to be considered, as well as the interplay between different levels of culture (Fayolle, Basso, \& Bouchard, 2010).

\section{Conclusion}

This chapter proposes a detailed explanation of the mechanisms through which culture may affect the entrepreneurial process. In this endeavour, we have built on several previous contributions, and particularly on the work of Autio et al (2013), Leung and Morris (2015) and Stephan et al. (2015). As far as we know, this is the first attempt to develop a complete model to explain the different effect of alternative cultural elements (in interaction with the economic conditions) in the process from entrepreneurial intention to start-up behaviour. Nevertheless, a large number of questions remain open and need to be addressed. In particular, the propositions posed need to be developed as testable hypotheses and checked against data. Additionally, the implications of this model need to 
be derived. We call for researchers to work, develop or refute these propositions and the model upon which they are based.

\section{References}

Ajzen, I. (1991). The Theory of Planned Behavior. Organizational Behavior and Human Decision Processes, 50(2), 179-211. Retrieved from http://people.umass.edu/aizen/tpb.html

Audretsch, D. B., \& Fritsch, M. (1999). The Industry Component of Regional New Firm Formation Processes. Review of Industrial Organization, 15(3), 239-252.

Autio, E., Pathak, S., \& Wennberg, K. (2013). Consequences of cultural practices for entrepreneurial behaviors. Journal of International Business Studies, 44(4), 334362.

Baker, T., Gedajlovic, E., \& Lubatkin, M. (2005). A framework for comparing entrepreneurship processes across nations. Journal of International Business Studies, 36(5), 492-504.

Bardi, A., \& Schwartz, S. H. (2003). Values and behavior: Strength and structure of relations. Personality and Social Psychology Bulletin, 29(10), 1207-1220.

Berings, D., \& Adriaenssens, S. (2012). The role of business ethics, personality, work values and gender in vocational interests from adolescents. Journal of Business Ethics, 106(3), 325-335.

Bianchi, M. (2010). Credit constraints, entrepreneurial talent, and economic development. Small Business Economics, 34(1), 93-104. https://doi.org/10.1007/s11187-009-9197-3

Bird, B. (1988). Implementing entrepreneurial ideas: the case for intention. Academy of Management Review, 13(3), 442-453.

Bjornskov, C., \& Foss, N. J. (2006). Economic freedom and entrepreneurial activity: Some cross-country evidence. DRUID Working Paper, 06-18.

Boehnke, K. (2001). Parent-Offspring Value Transmission in a Societal Context: Suggestions for a Utopian Research Design-- with Empirical Underpinnings. Journal of Cross-Cultural Psychology, 32(2), 241-255.

Bourdieu, P. (1991). Language and Symbolic Power. Cambridge: Polity Press.

Busenitz, L. W., \& Lau, C. M. (1996). A cross-cultural cognitive model of new venture creation. Entrepreneurship Theory and Practice, 20(4), 25-39.

Carree, M. A., van Stel, A., Thurik, A. R., \& Wennekers, A. R. M. (2002). Economic development and business ownership: an analysis using data of 23 OECD countries in the period 1976-1996. Small Business Economics, 19(3), 271-290.

Carree, M. A., Van Stel, A., Thurik, R., \& Wennekers, A. R. M. (2007). The relationship between economic development and business ownership revisited. Entrepreneurship and Regional Development, 19(3), 281-291.

Cullen, J. B., Johnson, J. L., \& Parboteeah, K. P. (2014). National Rates of Opportunity Entrepreneurship Activity: Insights From Institutional Anomie Theory. Entrepreneurship Theory and Practice, 38(4), 775-806. https://doi.org/10.1111/etap.12018

Davidsson, P. (1995). Culture, structure and regional levels of entrepreneurship. Entrepreneurship and Regional Development, 7(1), 41-62.

Davidsson, P., \& Wiklund, J. (1997). Values, beliefs and regional variations in new firm formation rates. Journal of Economic Psychology, 18(2-3), 179-199. 
De Clercq, D., Lim, D. S. K., \& Oh, C. H. (2014). Hierarchy and conservatism in the contributions of resources to entrepreneurial activity. Small Business Economics, 42(3), 507-522. https://doi.org/10.1007/s11187-013-9515-7

Douglas, E. J., \& Shepherd, D. A. (2000). Entrepreneurship as a utility maximizing response. Journal of Business Venturing, 15(3), 231-251.

Douglas, E. J., \& Shepherd, D. A. (2002). Self-Employment as a Career Choice: Attitudes, Entrepreneurial Intentions, and Utility Maximization. Entrepreneurship Theory and Practice, 26(3), 81-90.

Earley, P. C., \& Gibson, C. B. (1998). Taking stock in our progress on individualismcollectivism: 100 years of solidarity and community. Journal of Management, 24(3), 265-304.

Etzioni, A. (1987). Entrepreneurship, adaptation and legitimation: a macro-behavioral perspective. Journal of Economic Behavior \& Organization, 8(2), 175-189.

Fayolle, A., Basso, O., \& Bouchard, V. (2010). Three levels of culture and firms' entrepreneurial orientation: A research agenda. Entrepreneurship and Regional Development, 22(7-8), 707-730.

Fayolle, A., Liñán, F., \& Moriano, J. A. (2014). Beyond Entrepreneurial Intentions: Values and Motivations in Entrepreneurship. International Entrepreneurship and Management Journal, 10(4), 679-689. https://doi.org/10.1007/s11365-014-0306-7

Fernández-Serrano, J., \& Romero, I. (2014). About the interactive influence of culture and regulatory barriers on entrepreneurial activity. International Entrepreneurship and Management Journal, 10(4), 781-802. https://doi.org/10.1007/s11365-0140296-5

Fischer, R. (2006). Congruence and functions of personal and cultural values: Do my values reflect my culture's values? Personal and Social Psychology Bulletin, 32(11), 1419-1431.

Fischer, R., \& Schwartz, S. H. (2011). Whence Differences in Value Priorities?: Individual, Cultural, or Artifactual Sources. Journal of Cross-Cultural Psychology, 42(7), 1127-1144. https://doi.org/10.1177/0022022110381429

Fishman, R., \& Sarria-Allende, V. (2004). Regulation of entry and the distortion of industrial organization. Working Paper No. 10929. Cambridge, MA: National Bureau of Economic Research.

Fiske, S. T., \& Taylor, S. E. (2013). Social cognition: From brains to culture (2nd ed.). Thousand Oaks, CA: Sage PublicationS.

Fritsch, M., \& Mueller, P. (2004). Effects of New Business Formation on Regional Development over Time. Regional Studies, 38(8), 961-975.

García-Cabrera, A. M., \& García-Soto, M. G. (2008). Cultural differences and entrepreneurial behaviour: an intra-country cross-cultural analysis in Cape Verde. Entrepreneurship and Regional Development, 20(5), 451. Retrieved from http://proquest.umi.com/pqdweb?did=1553514561\&Fmt=7\&clientId=35935\&RQ $\mathrm{T}=309 \& \mathrm{VName}=\mathrm{PQD}$

Gennaioli, N., La Porta, R., Lopez-de-Silanes, F., \& Shleifer, A. (2013). Human Capital and Regional Development. Quarterly Journal of Economics, 128(1), 105-164. https://doi.org/10.1093/qje/qjs050

Hayton, J. C., \& Cacciotti, G. (2013). Is there an entrepreneurial culture? A review of empirical research. Entrepreneurship \& Regional Development, 25(9-10), 708-731. https://doi.org/10.1080/08985626.2013.862962

Hayton, J. C., George, G., \& Zahra, S. A. (2002). National culture and entrepreneurship: a review of behavioral research. Entrepreneurship Theory and Practice, 26(4), 3352. 
Henrekson, M. (2005). Entrepreneurship: A weak link in the welfare state? Industrial and Corporate Change, 14(3), 437-467.

Hirschi, A., \& Fischer, S. (2013). Work Values as Predictors of Entrepreneurial Career Intentions: A Longitudinal Analysis of Gender Effects. Career Development International, 18(3), 216-231.

Hofstede, G. (1980). Culture's consequences: international differences in work-related values. Beverly Hills: Sage Publications.

Hofstede, G. (2003). Culture's consequences: comparing values, behaviors, institutions and organizations across nations (2nd ed.). Newbury Park: Sage Publications.

Hofstede, G., \& Hofstede, G. J. (2005). Cultures and Organizations, Software of the Mind. New York: McGraw-Hill.

Holland, D. V, \& Shepherd, D. A. (2013). Deciding to Persist: Adversity, Values, and Entrepreneurs' Decision Policies. Entrepreneurship Theory and Practice, 37(2), 331-358. https://doi.org/10.1111/j.1540-6520.2011.00468.x

Hoogendoorn, B. (2016). The Prevalence and Determinants of Social Entrepreneurship at the Macro Level. Journal of Small Business Management, 54(S1), 278-296.

House, R., Javidan, M., Hanges, P., \& Dorfman, P. (2002). Understanding cultures and implicit leadership theories across the globe: an introduction to project GLOBE. Journal of World Business, 37(1), 3-10.

Iakovleva, T., Kolvereid, L., \& Stephan, U. (2011). Entrepreneurial intentions in developing and developed countries. Education + Training, 53(5), 353-370. https://doi.org/10.1108/00400911111147686

Inglehart, R. (1997). Modernization and Postmodernization. Princeton: Princeton University Press.

Jabri, M. M. (2005). Commentaries and Critical Articles: Text-context Relationships and Their Implications for Cross Cultural Management. International Journal of Cross Cultural Management, 5(3), 349-360.

Jaén, I., \& Liñán, F. (2013). Work values in a changing economic environment: The role of entrepreneurial capital. International Journal of Manpower, 34(8), 939-960. https://doi.org/10.1108/IJM-07-2013-0166

Jaén, I., \& Liñán, F. (2015). Cultural values in the study of a society's entrepreneurial potential. In A. Fayolle, P. Kyro, \& F. Liñán (Eds.), Developing, Shaping and Growing Entrepreneurship (pp. 154-177). Cheltenham (UK): Edward Elgar Pub. https://doi.org/10.4337/9781784713584.00015

Javidan, M., House, R. J., Dorfman, P. W., Hanges, P. J., \& De Luquet, M. S. (2006). Conceptualizing and Measuring Cultures and Their Consequences: A Comparative Review of GLOBE's and Hofstede's Approaches. Journal of International Business Studies, 37(6), 897-914.

Jovanovic, T. B. (1993). The Diversification of Production. Brookings Papers on Economic Activity, Microeconomics, 1993(1), 197-235.

Kautonen, T., van Gelderen, M., \& Fink, M. (2015). Robustness of the theory of planned behavior in predicting entrepreneurial intentions and actions. Entrepreneurship Theory and Practice, 39(3), 655-674. https://doi.org/10.1111/etap.12056

Kautonen, T., Van Gelderen, M., \& Tornikoski, E. T. (2013). Predicting entrepreneurial behaviour: a test of the theory of planned behaviour. Applied Economics, 45(6), 697707. https://doi.org/http://dx.doi.org/10.1080/00036846.2011.610750

Kelley, D. J., Singer, S., \& Herrington, M. (2016). Global Entrepreneuship Monitor 2015/16 Global Report. London.

Kibler, E., \& Kautonen, T. (2014). The moral legitimacy of entrepreneurs: An analysis of early-stage entrepreneurship across 26 countries. International Small Business 
Journal, 34(1), 34-50. https://doi.org/10.1177/0266242614541844

Kibler, E., Kautonen, T., \& Fink, M. (2014). Regional Social Legitimacy of Entrepreneurship: Implications for Entrepreneurial Intention and Start-up Behaviour. Regional Studies, 48(6), 995-1015. https://doi.org/10.1080/00343404.2013.851373

Krueger, N. F., Liñán, F., \& Nabi, G. (2013). Cultural values and entrepreneurship. Entrepreneurship and Regional Development, 25(9-10), 703-707. https://doi.org/10.1080/08985626.2013.862961

Krueger, N. F., Reilly, M. D., \& Carsrud, A. L. (2000). Competing models of entrepreneurial intentions. Journal of Business Venturing, 15(5-6), 411-432.

Langowitz, N., \& Minniti, M. (2007). The entrepreneurial propensity of women. Entrepreneurship Theory and Practice, 31(3), 341-364.

Lee, S. M., \& Peterson, S. J. (2000). Culture, entrepreneurial orientation, and global competitiveness. Journal of World Business, 35(4), 401-416.

Leung, K., \& Morris, M. W. (2015). Values, schemas, and norms in the culture-behavior nexus: A situated dynamics framework. Journal of International Business Studies, 46(9), 1028-1050.

Levesque, M., \& Minniti, M. (2006). The effect of aging on entrepreneurial behavior. Journal of Business Venturing, 21(2), 177-194.

Liao, J. W., \& Welsch, H. (2005). Roles of social capital in venture creation: Key dimensions and research implications. Journal of Small Business Management, 43(4), 345-362.

Liñán, F., \& Chen, Y. W. (2009). Development and cross-cultural application of a specific instrument to measure entrepreneurial intentions. Entrepreneurship: Theory and Practice, 33(3), 593-617. https://doi.org/10.1111/j.1540-6520.2009.00318.x

Liñán, F., \& Fayolle, A. (2015). A systematic literature review on entrepreneurial intentions: citation, thematic analyses, and research agenda. International Entrepreneurship and Management Journal, 11(4), 907-933. https://doi.org/10.1007/s11365-015-0356-5

Liñán, F., \& Fernandez-Serrano, J. (2014). National culture, entrepreneurship and economic development: different patterns across the European Union. Small Business Economics, 42(4), 685-701. https://doi.org/10.1007/s11187-013-9520-x

Liñán, F., Fernández-Serrano, J., \& Romero, I. (2013). Necessity and opportunity entrepreneurship: The mediating effect of culture. Revista de Economía Mundial, 33, 21-47.

Liñán, F., Moriano, J. A., \& Jaén, I. (2016). Individualism and entrepreneurship: Does the pattern depend on the social context? International Small Business Journal, 34(6), 760-776.

Lyons, S. T., Duxbury, L., \& Higgins, C. (2007). An empirical assessment of generational differences in basic human values. Psychological Reports, 101(2), 339-352. https://doi.org/10.2466/pr0.101.2.339-352

Markus, H. R., \& Kitayama, S. (1991). Culture and the self: Implications for cognition, emotion and motivation. Psychological Review, 98, 224-253.

McClelland, D. C. (1961). The achieving society. Princeton, N.J ; London: Van Nostrand.

McGrath, R. G., MacMillan, I. C., Yang, E. A., \& Tsai, W. (1992). Does Culture Endure, or Is It Malleable? Issues for Entrepreneurial Economic Development. Journal of Business Venturing, 7(6), 441-458.

Minniti, M., Bygrave, W. D., \& Autio, E. (2006). GEM, Global Entrepreneurship Monitor, 2005 Executive Report. London, U.K. \& Babson Park, MA: London Business School \& Babson College. 
Moriano, J. A., Gorgievski, M., Laguna, M., Stephan, U., \& Zarafshani, K. (2012). A Cross-Cultural Approach to Understanding Entrepreneurial Intention. Journal of Career Development, 39(2), 162-185. https://doi.org/10.1177/0894845310384481

Moriano, J. A., Palací, F. J., \& Morales, J. F. (2007). The Psychosocial Profile of the University Entrepreneur. Psychology in Spain, 11, 72-84.

Mueller, S. L., \& Thomas, A. S. (2001). Culture and entrepreneurial potential: A nine country study of locus of control and innovativeness. Journal of Business Venturing, 16(1), 51-75.

Mueller, S. L., Thomas, A. S., \& Jaeger, A. M. (2002). National entrepreneurial potential: the role of culture, economic development and political history. In M. A. Hitt \& J. L. C. Cheng (Eds.), Managing Transnational Firms: Resources, Market Entry and Strategic Alliances (Vol. 14, pp. 221-257). Amsterdam: JAI Press.

Naudé, W. (2010). Entrepreneurship, developing countries, and development economics: new approaches and insights. Small Business Economics, 34(1), 1-12. https://doi.org/10.1007/s11187-009-9198-2

Noorderhaven, N., Thurik, R., Wennekers, A. R. M., \& van Stel, A. (2004). The role of dissatisfaction and per capita income in explaining self-employment across 15 European countries. Entrepreneurship Theory and Practice, 28(5), 447-466.

North, D. C. (1995). The New Institutional Economics and Third World Development. In J. Harris, J. Hunter, \& C. M. Lewis (Eds.), The New Institutional Economics and Third World Development (pp. 17-26). London: Routledge. https://doi.org/10.1080/713701070

Noseleit, F. (2010). The entrepreneurial culture: guiding principles of the self-employed. In A. Freytag \& A. R. Thurik (Eds.), Entrepreneurship and Culture (pp. 41-54). New York: Springer.

Parker, S. C., \& Robson, M. (2004). Explaining International Variations in SelfEmployment: Evidence from a Panel of OECD Countries. Southern Economic Journal, 71(2), 287-301.

Phalet, K., \& Schonpflug, U. (2001). Intergenerational Transmission of Collectivism and Achievement Values in Two Acculturation Contexts: The Case of Turkish Families in Germany and Turkish and Moroccan Families in the Netherlands. Journal of Cross-Cultural Psychology, 32(2), 186-201. Retrieved from http://jcc.sagepub.com/cgi/doi/10.1177/0022022101032002006

Pinillos, M.-J. J., \& Reyes, L. (2011). Relationship between individualist-collectivist culture and entrepreneurial activity: evidence from Global Entrepreneurship Monitor data. Small Business Economics, 37(1), 23-37. https://doi.org/10.1007/s11187-0099230-6

Poschke, M. (2013). Who becomes an entrepreneur? Labor market prospects and occupational choice. Journal of Economic Dynamics and Control, 37(3), 693-710.

Pruett, M., Shinnar, R., Toney, B., Llopis, F., Fox, J., Mark, P., ... Jerry, F. (2009). Explaining entrepreneurial intentions of university students: a cross-cultural study. International Journal of Entrepreneurial Behaviour \& Research, 15(6), 571. Retrieved from http://proquest.umi.com/pqdweb?did=1963641321\&Fmt=7\&clientId=35935\&RQ $\mathrm{T}=309 \& \mathrm{VName}=\mathrm{PQD}$

Rauch, A., \& Frese, M. (2007). Let's put the person back into entrepreneurship research: A meta-analysis on the relationship between business owners' personality traits, business creation, and success. European Journal of Work and Organizational Psychology, 16(4), 353-385.

Rauch, A., Frese, M., Wang, Z.-M., Unger, J., Lozada, M., Kupcha, V., \& Spirina, T. 
(2013). National culture and cultural orientations of owners affecting the innovation-growth relationship in five countries. Entrepreneurship \& Regional Development, 25(9-10), 732-755.

Reynolds, P. D., Bygrave, W., Autio, E., \& Hay, M. (2002). Global Entrepreneurship Monitor. 2002 summary report. Kansas City: Ewin Marion Kauffman Foundation.

Reynolds, P. D., Storey, D. J., \& Westhead, P. (1994). Cross-national comparison of the variation in new firm rates. Regional Studies, 28(4), 443-456.

Ros, M. (2002). Los valores culturales y el desarrollo socioeconómico: una comparación entre teorías culturales. Revista Española de Investigaciones Sociológicas, 99, 9-33.

Sackmann, S. A., \& Phillips, M. E. (2004). Contextual Influences on Culture Research: Shifting Assumptions for New Workplace Realities. International Journal of Cross Cultural Management, 4(3), 370-390. https://doi.org/10.1177/1470595804047820

Schwartz, S. H. (1990). Individualism-Collectivism. Critique and proposed refinements. Journal of Cross-Cultural Psychology, 21(2), 139-157.

Schwartz, S. H. (1992). Universals in the content and structure of values: Theoretical advances and empirical tests in 20 countries. In M. P. Zanna (Ed.), Advances in Experimental Social Psychology (Vol. 25, pp. 1-65). New York: Academic Press.

Schwartz, S. H. (1994). Are there universal aspects in the structure and contents of human values? Journal of Social Issues, 50, 19-45.

Schwartz, S. H. (1999). A theory of cultural values and some implications for work. Applied Psychology: An International Review, 48(1), 23-47.

Schwartz, S. H. (2006). A Theory of Cultural Value Orientations: Explication and Applications. Comparative Sociology, 5(2-3), 2-3.

Schwartz, S. H. (2008). Cultural value orientations: Nature and implications of national differences. Moscow: Publishing House of SU HSE.

Schwartz, S. H. (2009). Culture matters. National value cultures, sources and consequences. In R. S. Wyer, C.-Y. Chiu, \& Y.-Y. Hong (Eds.), Understanding Culture: Theory, Research, and Application (pp. 127-150). New York: Psychology Press.

Shane, S. A. (1993). Cultural Influences on National Rates of Innovation. Journal of Business Venturing, 8(1), 59-73.

Shane, S. A., Kolvereid, L., \& Westhead, P. (1991). An Exploratory Examination of the Reasons Leading to New Firm Formation across Country and Gender. Journal of Business Venturing, 6(6), 431-446.

Shane, S. A., \& Venkataraman, S. (2000). The promise of entrepreneurship as a field of research. Academy of Management Review, 25(1), 217-226.

Siegel, J. I., Licht, A. N., \& Schwartz, S. H. (2013). Egalitarianism, Cultural Distance, and Foreign Direct Investment: A New Approach. Organization Science, 24(4), 1174-1194. https://doi.org/doi:10.1287/orsc.1120.0776

Steenkamp, J. B. (2001). The role of national culture in international marketing research. International Marketing Review, 18(1), 30-44.

Stephan, U., Uhlaner, L. M., \& Stride, C. (2015). Institutions and social entrepreneurship: The role of institutional voids, institutional support, and institutional configurations. Journal of International Business Studies, 46(3), 308-331.

Sternberg, R., \& Wennekers, A. R. M. (2005). Determinants and Effects of New Business Creation Using Global Entrepreneurship Monitor Data. Small Business Economics, 24(3), 193-203.

Tabellini, G. (2010). Culture and institutions: economic development in the regions of Europe. Journal of the European Economic Association, 8(4), 677-716.

Tang, L., \& Koveos, P. E. (2008). A framework to update Hofstede's cultural value 
indices: economic dynamics and institutional stability. Journal of International Business Studies, 39(6), 1045-1063.

Thornton, P. H., Ribeiro-Soriano, D., \& Urbano, D. (2011). Socio-cultural factors and entrepreneurial activity. International Small Business Journal, 29(2), 105-118. https://doi.org/10.1177/0266242610391930

Tiessen, J. H. (1997). Individualism, collectivism and entrepreneurship: A framework for international comparative research. Journal of Business Venturing, 12(5), 367-384.

Triandis, H. C. (1995). Individualism \& collectivism. New directions in social psychology. Boulder, CO; Oxford: Westview.

Urbano, D., \& Alvarez, C. (2014). Institutional dimensions and entrepreneurial activity: An international study. Small Business Economics, 42(4), 703-716.

van Gelderen, M., Brand, M., van Praag, M., Bodewes, W., Poutsma, E., \& van Gils, A. (2008). Explaining entrepreneurial intentions by means of the theory of planned behaviour. Career Development International, 13(6), 538-559. https://doi.org/10.1108/13620430810901688

Van Gelderen, M., Kautonen, T., \& Fink, M. (2015). From entrepreneurial intentions to actions: Self-control and action-related doubt, fear, and aversion. Journal of Business Venturing, 30(5), 655-673.

van Stel, A., \& Storey, D. J. (2004). The Link Between Firm Births and Job Creation: Is there a Upas Tree Effect? Regional Studies, 38(8), 893-909.

van Stel, A., Wennekers, A. R. M., Thurik, A. R., Reynolds, P. D., \& de Wit, G. (2003). Explaining nascent entrepreneurship across countries. SCALES-paper (Vol. SCALES). Zoetermeer: EIM Business and Policy Research.

Verheul, I., Wennekers, A. R. M., Audretsch, D. B., \& Thurik, A. R. (2002). An eclectic theory of entrepreneurship. In D. B. Audretsch, A. R. Thurik, I. Verheul, \& A. R. M. Wennekers (Eds.), Entrepreneurship: Determinants and Policy in a European-US Comparison. Boston/ Dordrecht: Kluwer Academic Publishers.

Wdowiak, M. A., Schwarz, E. J., Breitenecker, R. J., \& Wright, R. W. (2007). Linking the cultural capital of the entrepreneur and early performance of new ventures: A crosscountry comparison. Journal for East European Management Studies, 17(2), 149183.

Wennekers, A. R. M., Uhlaner, L. M., \& Thurik, A. R. (2002). Entrepreneurship and its conditions: A macro perspective. International Journal of Entrepreneurship Education, 1(1), 25-64.

Wennekers, A. R. M., van Stel, A., Thurik, A. R., \& Reynolds, P. D. (2005). Nascent Entrepreneurship and the Level of Economic Development. Small Business Economics, 24(3), 293-309.

Williams, L. K., \& McGuire, S. J. (2010). Economic creativity and innovation implementation: the entrepreneurial drivers of growth? Evidence from 63 countries. Small Business Economics, 34(4), 391-412.

Williamson, O. E. (2000). The New Institutional Economics: Taking Stock, Looking Ahead. Journal of Economic Literature, 38(3), 595-613. https://doi.org/10.2307/2565421

Xavier, S. R., Kelley, D. J., Kew, J., Herrington, M., \& Vorderwülbecke, A. (2013). Global Entrepreneurship Monitor (GEM) 2012 Global Report. Retrieved from http://www.gemconsortium.org/report/48545

Yang, K. P., Hsiung, H. H., \& Chiu, Y. J. (2015). The comfort zone of the value circumplex for entrepreneurship: a structural analysis. Career Development International, 20(6), 663-683. 